\title{
Modification of Streptozotocin-Induced Diabetes in Rats by Pretreatment with Cortisone*
}

\author{
K. F. Wellmann and B. W. Volk \\ Isaac Albert Research Institute of the Kingsbrook Jewish Medical Center, Brooklyn, New York, USA
}

\begin{abstract}
Summary. Cortisone pretreatment considerably enhances the mortality of young, male, streptozotocininjected Holtzman rats. In those that survive, cortisone pretreatment decreases the ensuing hyperglycaemia, extends the period during which streptozotocin-induced B cell damage can be observed from less than two to as much as four to seven days and permits the persistence of poorly granulated $B$ cells in such animals. These effects are at least partially attributable to a cortisone-induced augmentation of the total $\mathrm{B}$ cell mass. Compared with the high degree of protection against alloxan-induced damage afforded the pancreatic $B$ cells of cortisonepretreated rabbits, the protective effect of cortisone against B cell destruction in streptozotocin-injected rats is thus much more limited in scope. Species differences as well as differing pathogenetic mechanisms may account for these results.
\end{abstract}

Key words: Cortisone, B cell, blood glucose, experimental diabetes, islet hyperplasia, rat, streptozotocin.

In earlier experiments $[10,15-18]$ it has been shown that pretreatment with diabetogenic doses of cortisone protects rabbits against the $\mathrm{B}$ cell toxicity of alloxan and prevents the development of overt, alloxan-induced diabetes. In the study to be described, this model was employed in order to determine whether cortisone pretreatment also modifies streptozotocin-caused diabetes as seen in rats.

\footnotetext{
* Presented at the Ninth International Diabetes Federation
} Congress, New Delhi, India, October 31 - November 5, 1976

\section{Material and Methods}

One hundred and sixty young male Holtzman rats, each approximately 90 days old, were divided into four groups. Those of Group A, comprising 20 rats, were given cortisone acetate intramuscularly for a period of six weeks; daily doses amounted to $4 \mathrm{mg} / \mathrm{kg}$ for the first two, $8 \mathrm{mg} / \mathrm{kg}$ for the third and fourth and $16 \mathrm{mg} / \mathrm{kg}$ for the fifth and sixth weeks. The animals were killed at the end of the experimental period. Group B consisted of 40 animals, each of which was given a single intravenous injection of streptozotocin (65 mg/kg in saline). Group C was made up of 90 rats which were first treated for six weeks with cortisone, as specified for Group A, and were then given a single injection of $65 \mathrm{mg} / \mathrm{kg}$ of streptozotocin $24 \mathrm{~h}$ after the last dose of cortisone had been administered. The animals of Groups B and C were killed at various intervals ranging from 30 minutes to 100 days following the injection of streptozotocin. The ten rats of Group D served as untreated controls.

The animals were kept in pairs in metabolic cages and received rat chow (Purina) and tap water ad libitum. Blood was withdrawn from the tail vein in the non-fasted state at daily to weekly intervals. Blood glucose determinations were carried out by the Nelson-Somogyi method [12].

The rats were anaesthetized with ether and their pancreases immediately removed. A small portion of the organ was immersed in cold $1 \mathrm{~g} / 100 \mathrm{ml}$ osmium tetroxide with added sucrose [1] and cut into blocks less than $1 \mathrm{~mm}$. The blocks were fixed for 90 min in ice-cold osmium tetroxide, rinsed briefly in distilled water, dehydrated, and embedded in Epon 812 according to Luft [11]. Ultrathin sections were stained with uranyl acetate and lead citrate [14] and then viewed and photographed with an electron 


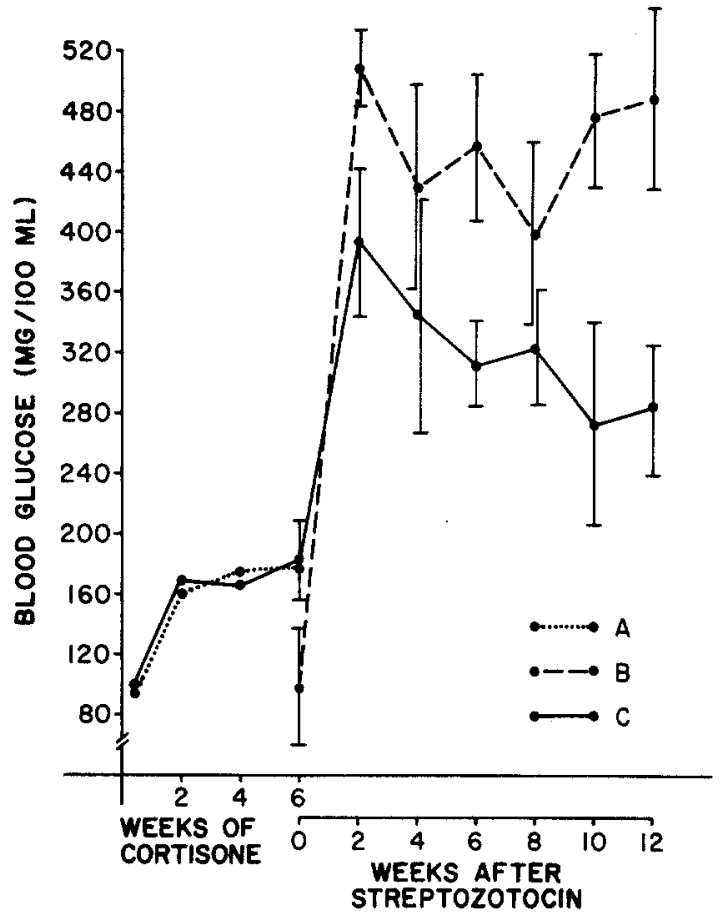

Fig. 1. Mean blood glucose values for the animals of the three experimental groups, with standard deviations for streptozotocintreated animals. A - cortisone only; B - streptozotocin only; C - cortisone followed by streptozotocin. The differences between groups $B$ and $C$ are statistically significant $(p<0.05)$ from the second week on for most points measured

microscope. The larger portion of the pancreas was placed in Zenker-formol solution. Paraffin-embedded sections were stained with haematoxylin and eosin, phosphotungstic acid haematoxylin, and with a modified aldehyde-fuchsin trichrome stain [5], as previously described [9].

\section{Results}

\section{Mortality}

There were striking differences in mortality between the three experimental groups. Whereas all animals of Group A (those that had been treated with cortisone alone) survived the experimental period, 15 of the 40 rats $(37.5 \%)$ of Group B (those that had received streptozotocin only) died spontaneously. In Group C (comprising cortisone-pretreated, streptozotocin-injected animals), no fewer than 69 of the 90 rats, or $76.7 \%$ of the total number, died. The large majority of deaths in Groups B and C occurred within the first 48 hours following the administration of streptozotocin.

\section{Blood Glucose Values}

The mean blood glucose values (Fig. 1) in the untreated control rats of Group D, as well as in the animals of all other groups before the initiation of treatment, were between 85 and $90 \mathrm{mg} / 100 \mathrm{ml}$. Cortisone treatment for six weeks (in Groups A and C) resulted in a gradual elevation of the mean blood glucose levels to about $180 \mathrm{mg} / 100 \mathrm{ml}$. Streptozotocin injection in the animals of Groups $B$ and $C$ was followed by an immediate sharp rise of the blood glucose values and by sustained hyperglycaemia during the ensuing 14 week observation period. However, streptozotocin-induced hyperglycaemia was significantly less pronounced in the cortisone-pretreated rats of Group $C$ when compared with the animals of Group B, which had not received cortisone (Fig. 1).

\section{Light Microscopy}

In histological sections stained with the aldehyde fuchsin trichrome method, the islets of untreated control rats contained numerous, well granulated (purple) B cells surrounded by lighter staining, orange-red A and grayish-green D cells (Fig. 2). The islets of the cortisone-treated rats of Group A appeared large and hyperplastic and contained predominantly poorly to moderately well staining B cells. The injection of streptozotocin in animals of Group B was followed by extensive and severe damage confined to the pancreatic B cells. Nuclear pyknosis, loss of cellular definition, clumping of the cytoplasm and eventual necrosis and disintegration of the cell were noted (Fig. 3). The first of these cellular changes was seen two to four hours after the injection of streptozotocin. Damage was most pronounced after 16 to $24 \mathrm{~h}$ and all B cells had disappeared from the islets by the end of the second day, so that after two and more days only A and D cells were identifiable. In cortisone-pretreated rats of Group C, identical lesions were observed after the injection of streptozotocin (Fig. 4). However, in these Group $C$ animals, in contrast to those of Group B, the islets appeared larger than in control animals and damaged $B$ cells were often still present two to four (or even seven) days after the administration of this compound. While, during later stages, no $B$ cells were identifiable in the islets of any of the Group B rats (Fig. 5), save one, small numbers of generally poorly staining B cells were present in most islets of all surviving animals of Group C (Fig. 6). The table provides quantitative data for selected light and electron microscopic changes in rats of Groups B and C.

\section{Electron Microscopy}

The ultrastructural examination of the islets of rats from Group A, after six weeks of cortisone treatment, revealed intact cellular constituents. The B cells were often poorly granulated, the profiles of 

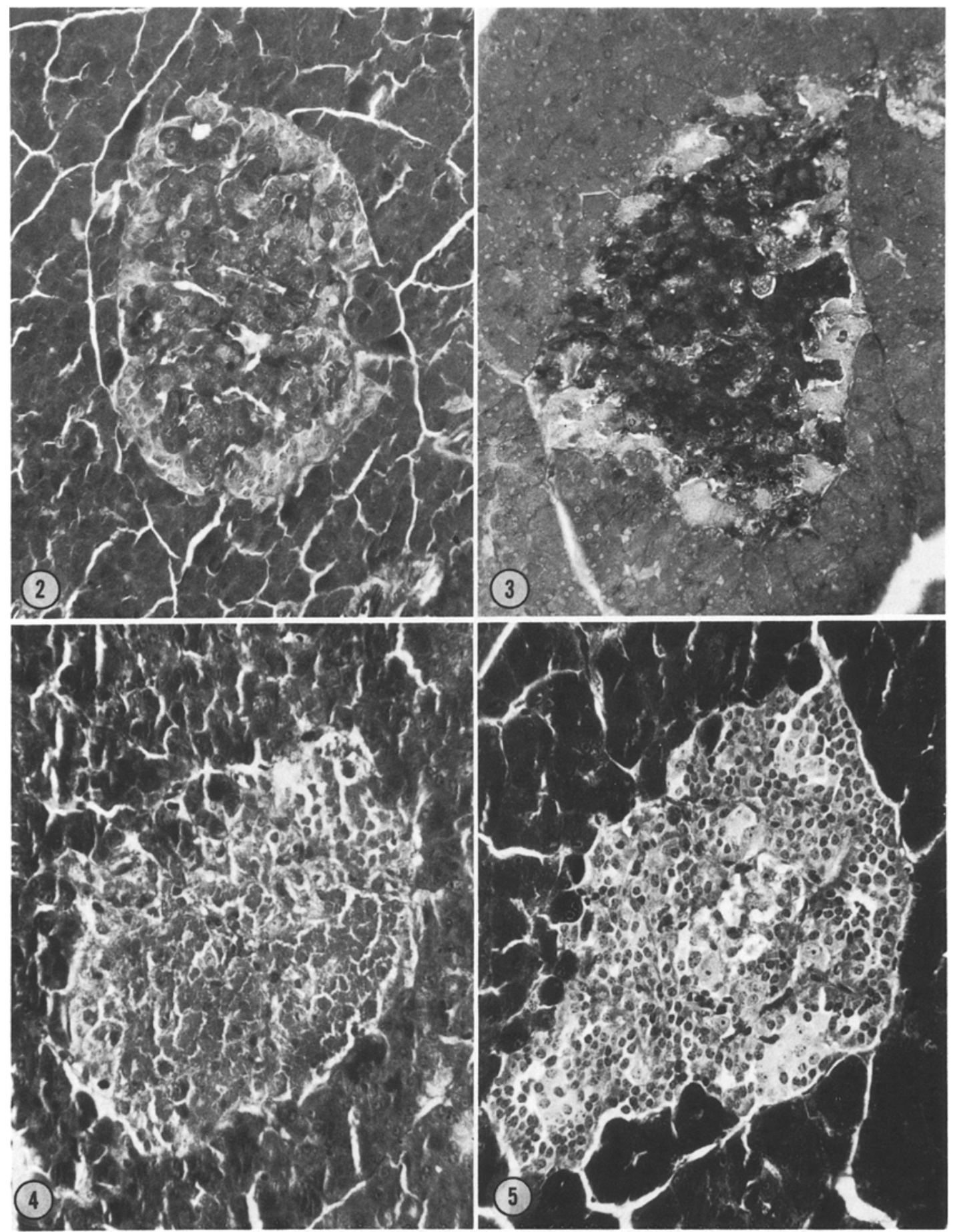

Fig. 2. Light photomicrograph of islet of untreated control rat (Group D). Well granulated B cells (dark cytoplasm) are surrounded by lighter staining A and D cells. Aldehyde fuchsin trichrome stain. $\times 320$

Fig. 3. Rat of Group B, $16 \mathrm{~h}$ after the injection of streptozotocin. The B cells are heavily damaged as evidenced by nuclear pyknosis and loss of cellular definition. The A and D cells appear intact. Aldehyde fuchsin trichrome stain. $\times 238$

Fig. 4. Cortisone-pretreated animal of Group C, $48 \mathrm{~h}$ after the injection of streptozotocin. Massive necrosis of B cells is evident. Aldehyde fuchsin trichrome stain. $\times 320$

Fig. 5. Rat of Group B, 14 days after streptozotocin injection. Tinctorially, all constituents of this islet are either A cells (darker cytoplasm) or D cells (lighter cytoplasm). Aldehyde fuchsin trichrome stain. $\times 320$ 


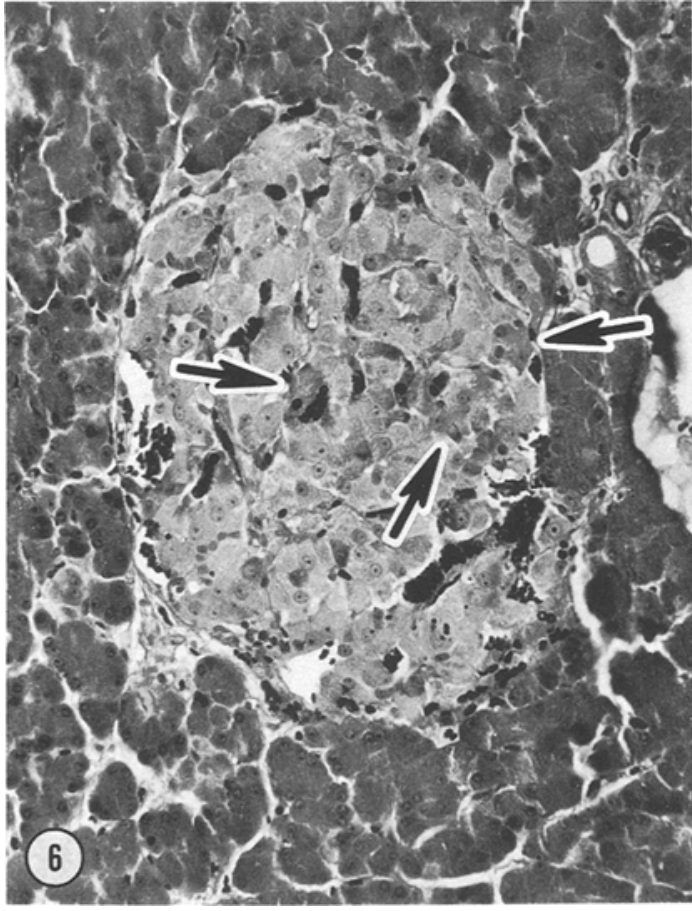

Fig. 6. Cortisone-pretreated rat of Group C, 7 days after streptozotocin injection. In addition to $A$ and $D$ cells, a fair number of poorly granulated B cells (arrows) have survived. Aldehyde fuchsin trichrome stain. $\times 238$

Table 1. Quantitation of selected light and electron microscopic changes in rats of Groups B and C

\begin{tabular}{llll}
\hline & \multicolumn{2}{l}{$\begin{array}{l}\text { Cases with damaged } \\
\text { B cells }\end{array}$} & $\begin{array}{l}\text { Cases with } \\
\text { identifiable } \\
\text { B cells after } \\
\text { day 7 }\end{array}$ \\
\cline { 2 - 4 } & Days 1 \& 2 & Days 4-7 & $1 / 7$ \\
\hline $\begin{array}{l}\text { Group B } \\
\text { (Streptozotocin } \\
\text { only) }\end{array}$ & $10 / 10$ & $0 / 8$ & $(14 \%)$ \\
\hline $\begin{array}{l}\text { Group C } \\
\text { (Cortisone } \\
\text { followed by } \\
\text { streptozotocin) }\end{array}$ & $(100 \%)$ & $(0 \%)$ & $6 / 6$ \\
\hline
\end{tabular}

the endoplasmic reticulum were dilated, and occasional cytoplasmic glycogen deposits were noted. In animals of Group B examined two hours after the injection of streptozotocin, early B cell damage was apparent in the form of incipient pyknotic condensation of the nuclear chromatin and a widening of the spaces between the cores and membranes of the secretory granules. After four hours, these changes had become more pronounced (Fig. 7); nuclear pyknosis was far advanced, the perigranular spaces were greatly distended, and the endoplasmic reticulum showed vesicular distension. Sixteen hours after streptozotocin administration, macrophages were seen to phagocytose the disintegrating, necrotic B cells. By the end of the second day, all B cells and the macrophages had disappeared and the islets consisted of non-B cells exclusively. In the cortisonepretreated rats of Group C, streptozotocin-induced B cell damage was similar to that seen in Group B animals (Fig. 8). However, surviving B cells were often encountered in Group C islets; four to seven days after the streptozotocin injection they still displayed cytoplasmic rarefaction and distortion of granules (Fig. 9). Thereafter the residual B cells recovered and, during later stages, the B cells showed prominent Golgi apparatus and appeared poorly granulated (Fig. 10). In the animals surviving longest, the B cells appeared poorly granulated and cytoplasmic glycogen deposits were noted in both $\mathrm{A}$ and $\mathrm{B}$ cells (Fig. 10).

\section{Discussion}

Rabbits pretreated with cortisone acetate fail to become overtly diabetic after injection of the B cell cytotoxin, alloxan [10, 15-18]. Instead, these animals develop a "subdiabetic" state, characterized by normoglycaemic blood glucose values, that changes to frank diabetes only in stress situations, for instance, when normally nondiabetogenic, small, repeated doses of cortisone are administered.

While cortisone thus protects the pancreatic B cells of rabbits against alloxan-induced destruction, the present experiment shows that cortisone fails to effectively prevent $B$ cell damage in rats injected with another B cell cytotoxin, streptozotocin. Nevertheless, cortisone does modify the B cell response of these animals to streptozotocin in two ways. Firstly, when administered alone, streptozotocin exerts its damaging effect within the initial $48 \mathrm{~h}$ after injection, so that by the end of the second post-streptozotocin day all B cells have disappeared from the islets. In cortisone-pretreated rats, however, damaged B cells may still be seen after four and even after seven days (Table 1). Secondly, while virtually no $B$ cells escape destruction in the streptozotocin-injected rat, the prior administration of cortisone permits at least some $B$ cells to survive (Table 1). This limited degree of $\mathrm{B}$ cell persistence in such animals is also reflected functionally by the lesser degree of hyperglycaemia (Fig. 1).

An important factor to be considered in an attempt to explain these differences is the observed hyperplasia of the islets of Langerhans, and specifically of the islet B cells, in the animals pretreated with cortisone. Such B cell hyperplasia induced by cortisone has previously been recorded in rats $[3,7]$, as well as in other mammalian species [6, 19]. Thus, at least some of the sparsely granulated B cells encountered in cortisone-treated animals (Fig. 10) 

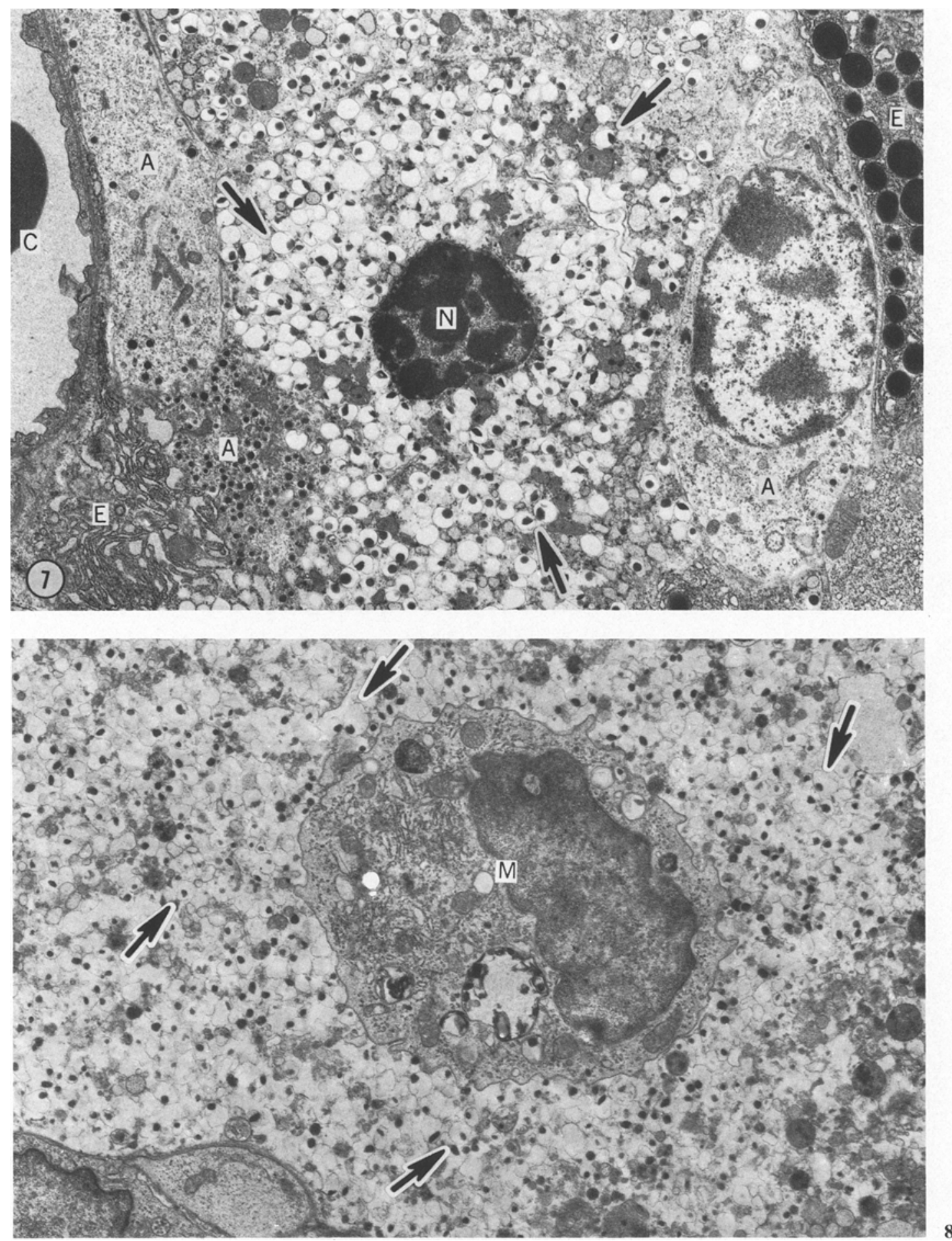

Fig. 7. Electron micrograph of islet tissue from animal of Group B, $4 \mathrm{~h}$ after the injection of streptozotocin. The nucleus (N) of a $\mathrm{B}$ cell is pyknotic, and the spaces between the distorted B cell granules and their membranes are greatly widened (arrows). The A cells (A) and the exocrine acinar cells $(\mathrm{E})$ appear intact. $\mathrm{C}-$ capillaries. $\times 6400$

Fig. 8. A macrophage (M) has moved into a damaged B cell of a cortisone-pretreated animal of Group C, 24 h after streptozotocin injection. The $\mathbf{B}$ cell granules (arrows) appear distorted, and the perigranular spaces are widened. $\times 8300$ 

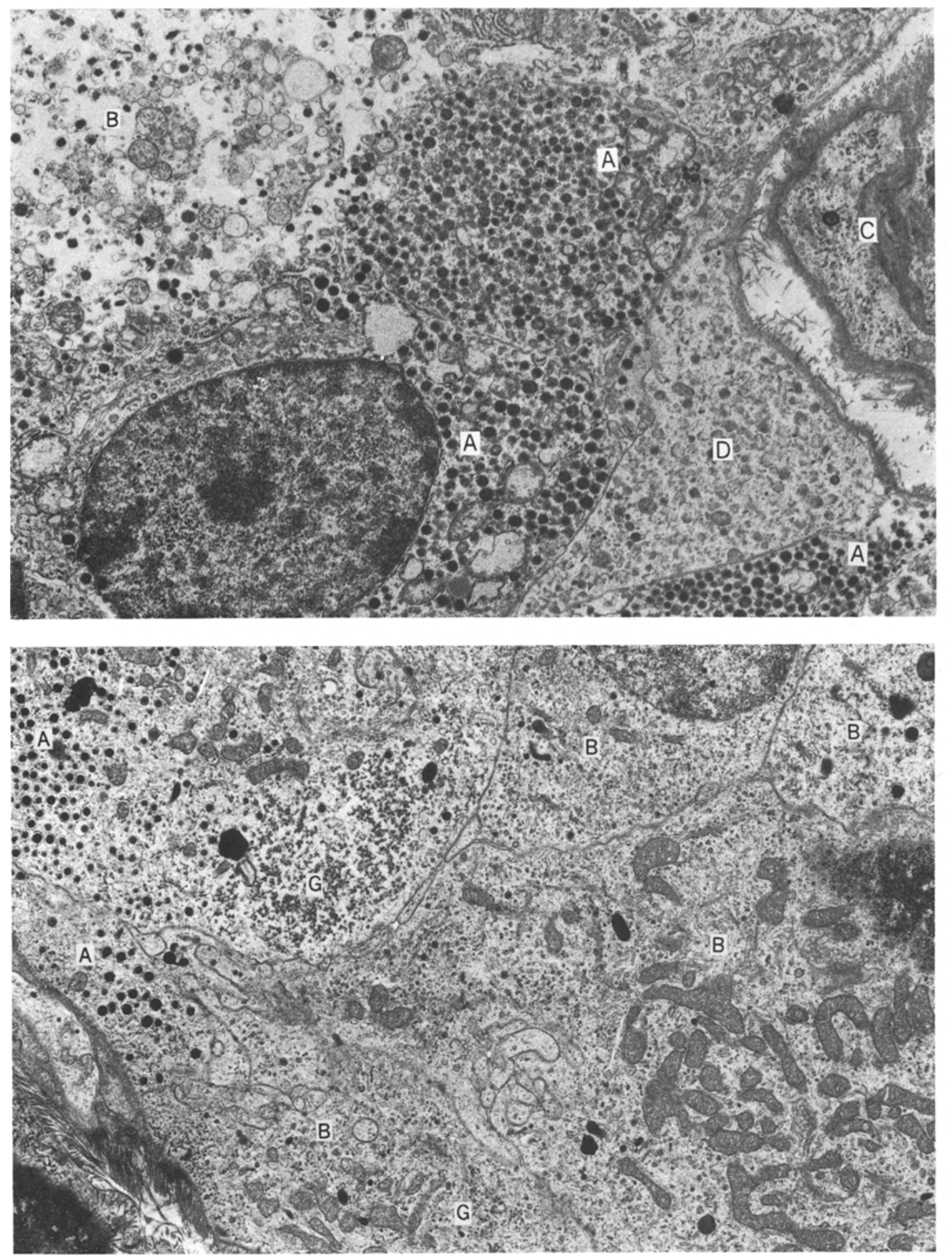

Fig. 9. Portion of islet of cortisone-pretreated rat of Group C, 4 days after the injection of streptozotocin. A surviving B cell (B) displays damage in form of cytoplasmic rarefaction and granular distortion. The A cells (A) and a D cell (D) appear intact. C - capillary. $\times 9900$

Fig. 10. Portion of islet of cortisone-pretreated rat of Group C, 100 days after streptozotocin administration. A cells (A) and what appear to be poorly granulated B cells $(B)$ are visible. Both cell types contain granular cytoplasmic glycogen deposits $(\mathrm{G})$. $\times 2800$ 
may represent young, regenerating B cells rather than degranulated, mature ones. It is likely that the increased B cell mass existing in such cortisonetreated animals contributed to the observed reduction of blood glucose levels by permitting more B cells to escape the cytotoxic effects of streptozotocin. Whether this mechanism is the only one through which cortisone exerts its modifying effect on streptozotocin remains undetermined.

A limited protective effect of cortisone pretreatment against streptozotocin-induced diabetes, and some of its complications, in rats, has also been observed by Koch et al. [8]. These authors "were astonished to find that in cortisol-treated diabetic animals there were lower blood glucose levels, fewer cases of glucosuria, and less pronounced cataracts than in rats treated with streptozotocin only". They concluded that the steroid had protected the pancreatic B cells from the deleterious effects of streptozotocin administration, but they do not provide morphologic data in support of these conclusions.

The limited protection of cortisone pretreatment against streptozotocin-induced, otherwise total abolition of B cell integrity, as recorded in this paper, is greatly offset by the considerably enhanced degree of mortality in animals so treated. On balance, then, the cortisone-streptozotocin model in rats, as tested, is not nearly as useful for the study of experimental diabetes, or subdiabetes, as is the previously described cortisone-alloxan combination in rabbits.

It is likely that some of the differences observed between the two models are attributable to differences between the two species studied. Also, and perhaps more importantly, the results reflect the well known fact that alloxan and streptozotocin damage the pancreatic $B$ cell by entirely different mechanisms. The available evidence supports the hypothesis that alloxan acts extracellularly on the B cell membrane [13], while streptozotocin enters the cell and appears to destroy it from within [2]. It should be noted, too, that other substances, including glutathione, cysteine, nicotinic acid, adrenaline, D-mannose and D-glucose, also protect against alloxan diabetes, but not against diabetes induced by streptozotocin $[4,13]$. While it is likely that the observed differences in the protective effect of cortisone against alloxan and streptozotocin are related to the differing modes by which these compounds exert their damage, there is no entirely satisfactory explanation of the pathogenetic mechanisms involved.

Acknowledgements. The authors are indebted to Mrs. Celina Mitgang, Mr. Charles Vibert, and Mr. Zoran Dordevic for valuable technical assistance, to Mrs. Renee Brenner for typing and editing the manuscript, and to Mr. Herbert A. Fischler, Chief Medi$\mathrm{cal}$ Photographer, for preparing the illustrations.

\section{References}

1. Caulfield, J. B.: Effects of varying the vehicle for $\mathrm{OsO}_{4}$ in tissue fixation. J. Biophys. Biochem. Cytol. 3, 827-830 (1957)

2. Dulin, W.D., Soret, M.G.: Chemically and hormonally induced diabetes. In: B. W. Volk, K.F. Wellmann (Eds.): The Diabetic Pancreas. New York: Plenum Press (in press)

3. Franckson, J. R. M., Gepts, W., Bastenie, P.A., Conard, V., Nordier, N., Kovacs, L.: Observations sur le diabète stéroide expérimental du rat. Acta Endocrinol. 14, 153-169 (1953)

4. Ganda, O.P., Rossini, A. A., Like, A. A.: Studies on streptozotocin diabetes. Diabetes 25, 595-603 (1976)

5. Gomori, G.: Aldehyde-fuchsin: new stain for elastic tissue. Am. J. Clin. Pathol. 20, 665-666 (1950)

6. Hausberger, F.X., Ramsay, A. J.: Steroid diabetes in guinea pigs: effects of hydrocortisone administration on blood and urinary glucose, nitrogen excretion, fat deposition, and the islets of Langerhans. Endocrinology 56, 533-540 (1955)

7. Houssay, B. A., Rodriguez, R. R., Cardeza, A. F.: Prevention of experimental diabetes with adrenal steroids. Endocrinology 54, 550-552 (1954)

8. Koch, H. R., Hillenblink, M., Liappis, N.: Über den Einfluß einer Hydrocortisonbehandlung auf die Entwicklung von diabetischen Linsentrübungen bei Ratten. Graefes Arch. Klin. Exp. Ophth. 200, 211-222 (1976)

9. Lazarus, S. S., Volk, B.W.: The Pancreas in Human and Experimental Diabetes pp. 261-262. New York: Grune \& Stratton 1962.

10. Lazarus, S.S., Volk, B. W.: Studies on a latent diabetic state in cortisone-alloxan treated rabbits. Diabetes 13, 54-59 (1964)

11. Luft, J. H.: Improvements in epoxy resin embedding methods. J. Biophys. Biochem. Cytol. 9, 409-414 (1961)

12. Nelson, N.: Photometric adaptation of Somogyi method for determination of glucose. J. Biol. Chem. 153, 375-380 (1944)

13. Rerup, C.C.: Drugs producing diabetes through damage of the insulin secreting cells. Pharmacol. Rev. 22, 485-518 (1970)

14. Reynolds, E. S.: The use of lead citrate at high pH as an electrono-paque stain in electron microscopy. J. Cell. Biol. 17, 208-212 (1963)

15. Volk, B.W., Lazarus, S. S.: Protection by cortisone pretreatment against alloxan diabetes. Arch. Pathol. 73, 363-370 (1962)

16. Volk, B. W., Lazarus, S.S., Wellmann, K. F.: Beta cell structure in latent and chronic diabetes in the rabbit. Diabetes 14, 792-804 (1965)

17. Volk, B. W., Wellmann, K. F., Lazarus, S.S.: Fine structure of rabbit pancreatic $B$ cells in cortisone-alloxan induced subdiabetes. Lab. Invest. 14, 1375-1391 (1965)

18. Wellmann, K.F., Brancato, P., Lazarus, S.S., Volk, B.W.: Rabbit beta cell ultrastructure and insulin radio-immunoassay in experimental subdiabetes. Arch. Pathol. 84, 251-263 (1967)

19. Wellmann, K.F., Volk, B. W.: Fine structure of pancreas in cortisone-treated guinea pigs and rabbits. Arch. Pathol. Lab. Med. 100, 334-338 (1976)

Received: December 24, 1976, and in revised form:

March 21, 1977

K. F. Wellmann, M. D.

Department of Pathology

Beekman Downtown Hospital

170 William Street

New York, NY 10038, USA

B. W. Volk, M. D.

Department of Pathology

Irvine Medical Center

101 City Drive South

Orange, CA 92668, USA 